\title{
The Prolific Variation, Body Morphometrics, and Breeding Value of Indonesian Local Etawah Goat Based in East Java
}

\author{
Mudawamah Mudawamah $^{1 *}$, Gatot Ciptadi ${ }^{2}$, Irawati Dinasari Retnaningtyas ${ }^{1}$ \\ ${ }^{1}$ Faculty of Animal Husbandry, Islamic University of Malang, Malang, Indonesia \\ ${ }^{2}$ Faculty of Animal Husbandry, Brawijaya University, Malang, Indonesia \\ * Corresponding email: mudawamah@unisma.ac.id
}

\begin{abstract}
A crucial trait of a high economic value of goats is calving to more than one kid (prolificacy potency). The high prolificacy potency (> $1 \mathrm{kid}$ ) has a higher income compared to single kids. This study described the potential of Indonesian Local Etawah Goat (ILEG) for prolific trait and the morphometric of body and breeding values in various environments as a basis for selection. It involved smallholder farmers who breed ILEG does from 14 villages in East Java. The research was conducted on a field survey to obtain primary data about the phenotypic superior ILEG goats based on the status of the prolific trait. The study used 520 does with 1347 prolific records obtained. The results showed that the prolificacy values ranged from 2.12-1.42 heads/calving (medium to high category). The variation of prolificacy was 0.53 , and the breeding values of the prolificacy trait were 1.48-1.74. The average of body morphometrics was varied with the following details. Chest circumference was $81.06 \pm 4.63 \mathrm{~cm}$, body length was $76.64 \pm 4.33 \mathrm{~cm}$, shoulder height was $75.34 \pm 5.83$ $\mathrm{cm}$ and ear length were $27.44 \pm 3.02 \mathrm{~cm}$. This study concluded that the prolific rate was medium to high category. The prolific variation was higher than body morphometry variation, and the prolificacy EBVs of breeding villages divided into four unique pattern boxplots. The prolific trait could be the basis for new considerations in the ILEG breeding program, either through selection or mating.
\end{abstract}

Keywords: doe, village breeding center, productivity

ABSTRAK. Salah satu sifat yang krusial dan bernilai ekonomi tinggi pada kambing adalah kemampuan melahirkan lebih dari satu anak (potensi prolifik). Potensi prolifik yang tinggi ( $>1$ anak) memiliki nilai ekonomi yang lebih tinggi dibandingkan dengan anak tunggal. Tujuan penelitian ini adalah untuk mengetahui potensi kambing Peranakan Etawah (PE) pada sifat prolifik dan morfometri tubuh serta nilai pemuliaan (EBV) di berbagai lingkungan sebagai dasar seleksi. Untuk mencapai tujuan tersebut maka penelitian ini melibatkan peternak rakyat yang membudidayakan PE yang berasal dari 14 wilayah pembibitan kambing di peternakan rakyat di Jawa Timur. Penelitian dilakukan dengan survei lapangan untuk mendapatkan data primer tentang fenotipe kambing PE unggul berdasarkan status sifat prolifiknya. Penelitian ini menggunakan 520 induk dengan 1.347 catatan prolifik. Hasil penelitian menunjukkan nilai prolifik berkisar antara 2,12-1,42 anak/kelahiran (kategori sedang sampai tinggi) dengan rerata variasi prolifik 0,53 dan EBV sebesar 1,48-1,74. Rataan morfometri tubuh adalah bervariasi dengan rincian berikut. Rataan lingkar dada sebesar 81,06 $\pm 4,63 \mathrm{~cm}$, panjang tubuh adalah 76,64 \pm 4,33 cm, tinggi pundak adalah 75,34 $\pm 5,83 \mathrm{~cm}$ dan panjang telinga adalah 27,44 $\pm 3,02 \mathrm{~cm}$. Kesimpulan dari penelitian ini adalah rataan prolifik kambing PE termasuk kategori sedang sampai tinggi. Variasi prolifik adalah lebih tinggi dibandingkan dengan morfometri tubuh dengan profil EBV prolifik terbagi empat pola unik boxplot. Sifat prolifik berpotensi menjadi dasar pertimbangan baru dalam program pemuliaan kambing PE baik melalui seleksi maupun perkawinan.

Kata kunci: Induk, village breeding center, productivitas

\section{Introduction}

Local livestock has been continuously investigated as a source of global germplasm. Smallholder farmers mainly raise indigenous goats as a common practice in the tropical and subtropical regions of Indonesia like East Java. Local goats are well adapted to the environment (feed and weather) and exhibit resistance to diseases (Bett et al., 2012; Goddard and Hayes,
2009; Mdladla et al., 2017; Mudawamah et al., 2019; Pai and Chakravarty, 2020; Schwartz, 2017).

The goat that has existed for decades and adapted to the Indonesian environment is the Indonesian Local Etawah Goats, abbreviated as ILEG (also known as PE goats in Indonesia). ILEG comes from the crossing of Etawah goats with indigenous or Kacang goats. Etawah Goat was 
earlier imported from India during preindependence era under the Dutch government. The characteristics of ILEG are the combination of Etawah goats from India and indigenous goats, with exterior features similar to those of Indian Etawah goats, such as a convex face with long, drooping ears. However, the body size is smaller than that of Etawah goats but bigger than Kacang goats (Mudawamah et al., 2015).

One of the contributing factors to the productivity of goats is the number of offspring per calving that exceeds one (He et al., 2001; Haldar et al., 2014). Such prolific trait would be well expressed if supported by a conducive environment (Ling et al., 2015). One of the representative areas for research is East Java province because it is the second-ranked region of 34 provinces in Indonesia regarding the number of goat populations (Ministry of Agriculture Republic of Indonesia, 2018). Therefore, the objective of this study is to examine the prolific of ILEG through genetic parameters and body morphometrics, and breeding values in breeding centers.

\section{Materials and Methods}

There were 140 farmers involved in this study with the criteria of having ILEG does calving at least two times. The numerators were the students from Animal Husbandry study program who were specifically pretrained by a team of experts to observe prolific data and measure body morphometrics, to conduct an interview with farmers, and to write data on recording paper.

The research method was a survey by purposive sampling. The prolific data was the primary data obtained from a face-to-face interview with each farmer in the goat houses while we pointed at a specific doe directly. The talk included the litter size of dams and the number of does that had calved. The farmer was interviewed in a cage while looking directly at the dam in a house, discussing the potential fecundity and measuring body morphometrics.
The farmer ownership was 3-10 does, and the calving number was 2-7 times.

Body morphometrics studied included eight types of measurement as follows: (1) chest circumference (CC) from the front of the ribs to just behind the front legs, (2) body length (BL) from a distance pulled straight from the shoulder joints (tubal humerus) to the lumps of the filter (Tuber ischiadicus), (3) shoulder height (SH) is the highest distance of Tuber coxae to bottom, (4) ears length (EL) from the range of the ear's base to the tip of the ear, (5) ears width (EW) from a distance between the edges of the ear, (6) tail length (TL) from the reach of the base of the hair tail to the tip of the hair tail, (7) length of hairtail (LHT) from the bottom to the most extended tail hair's end, and (8) pelvis height (PH) from the highest distance (Lumbar vertebrae) from perpendicular to the ground surface.

The selected 14 samples of rural regions in East Java included Banyuwangi Licin (BL), Blitar Ponggok (BP), Gresik Delik Sumber (GDS), Jombang Wonosalam (JW), Kediri Papar Bulurejo (KPB), Lumajang Bruno (LB), Malang Ampel Gading (MAG), Malang Dampit (MD), Malang Wonosari (MW), Nganjuk Sumber Urip (NSU), Sumenep-Kalianget (SK), SumenepPorteran (SP), Sumenep-Saronggi (SS), Trenggalek Sumber Bening (TSB). The necessary consideration was that the regions had does that calved at least one time, available feed resources and breeding regions.

The statistical analysis used one-way ANOVA and Least Square Difference (LSD) to know the difference body morphology among breeding village centers in East Java.

Heritability was estimated for the prolific traits of ILEG does and used dam-daughter relationship with formulas $h 2=2 \sigma 2 X / C O V X Y, n o$ correction data because the does parity and the environment were relatively identical. The repeatability estimates were analyzed using ANOVA's (Becker, 1992) with formulas $r=$ $\sigma 2 s /(\sigma 2 s+\sigma 2 w)$. The prolific data of genetic 
parameter estimations were from does calving at least three kids and the relatively same environment (feed and management).

The Estimated Breeding values (EBVs) were used to select goat ILEG candidates based on their prolificacy value. The formula as follows:

$$
E B V s=\frac{h^{2}}{1+(\mathrm{n}-1) \mathrm{r}}\left(P i-P_{P}\right)+P_{P}
$$

\section{Results and Discussions}

\section{Prolific Data of ILEG Does}

Results that obtained including data of prolific does in 14 difference villages in East Java (Table 1). Data gathered 1195 recording as prolificacy information, record from 452 does

Table 1. Mean and Phenotype Variance of ILEG in 14 Regions of East Java based on prolific traits

\begin{tabular}{llcccccc}
\hline No & Area Code & $\begin{array}{c}\text { Number of } \\
\text { prolific } \\
\text { data }\end{array}$ & $\begin{array}{c}\text { Number } \\
\text { of does }\end{array}$ & $\begin{array}{c}\text { The average } \\
\text { of birth } \\
\text { frequency }\end{array}$ & $\begin{array}{c}\text { Prolific average } \\
\text { (heads/calving) }\end{array}$ & $\begin{array}{c}\text { Prolific } \\
\text { variations } \\
\text { (VP) }\end{array}$ & $\begin{array}{c}\text { Average of } \\
\text { prolific } \\
\text { category }\end{array}$ \\
\hline 1 & BL & 105 & 49 & 1.74 & 1.42 & 0.53 & Medium \\
2 & BP & 114 & 47 & 2.06 & 1.75 & 0.46 & Medium \\
3 & GDS & 85 & 49 & 1.67 & 1.48 & 0.50 & Medium \\
4 & JW & 100 & 53 & 1.69 & 1.84 & 0.47 & High \\
5 & KDR & 48 & 27 & 1.81 & 1.71 & 0.21 & Medium \\
6 & LB & 136 & 55 & 2.01 & 1.76 & 0.56 & Medium \\
7 & MAG & 116 & 26 & 2.79 & 2.12 & 0.69 & High \\
8 & MD & 105 & 60 & 1.87 & 1.75 & 0.72 & Medium \\
9 & MW & 327 & 39 & 2.94 & 1.84 & 0.48 & High \\
10 & NSU & 39 & 22 & 2.05 & 1.77 & 0.67 & Medium \\
11 & SK & 19 & 16 & 1.95 & 1.58 & 0.51 & Medium \\
12 & SP & 37 & 16 & 1.84 & 1.68 & 0.53 & Medium \\
13 & SS & 51 & 42 & 2.00 & 1.49 & 0.50 & Medium \\
14 & TSB & 65 & 19 & 2.50 & 1.81 & 0.58 & Medium \\
& Total & 1347 & 520 & 28.92 & 24.00 & 7.41 & Medium \\
\hline
\end{tabular}

Table 1. showed that the does with a calving rate at least twice had an average number of calving of $1.72 \mathrm{kids} / \mathrm{doe}$, the highest value of $2.12 \mathrm{kids} / \mathrm{doe}$, and the lowest value of 1.42 kids/doe and the medium category. The number of kids per calving from ILEG is higher than that of goats in Romania, with average kids per calving of $1.30 \mathrm{kids} / \mathrm{doe}$ (Pascal and Zaharia, 2016) and $1.43 \mathrm{kids} /$ doe of Serrana goat (Margatho et al., 2019), 1.63 kids/doe of Begait goat (Abraham et al., 2018). It was almost the same as the average number of kids at German Improved Fawn goats with the kids per calving around1.70 kids/doe (Samardzija et al., 2013), and the ordinary calving of Saanen goats were 1.74 kids/doe (Kasap et al., 2013).

\section{Morphometric Body of ILEG Does}

The average morphometric body components included $\mathrm{CC}, \mathrm{BL}, \mathrm{BH}, \mathrm{EL}, \mathrm{EW}, \mathrm{TL}$,
LHT, and PH on ILEG Does in 14 different villages in East Java, could be seen in Table 2

The average morphometric body of the ILEG population (Table 2) at CC $81.06 \pm 4.63 \mathrm{~cm}, \mathrm{BL}$ $76.64 \pm 4.33 \mathrm{~cm}, \mathrm{SH} 75.34 \pm 5.83 \mathrm{~cm}$ and $\mathrm{EL}$ $27.44 \pm 3.02 \mathrm{~cm}$.

The average value was higher than the national standard for ILEG does (National Standard Agency, 2015), in which ILEG standards were CC $72 \mathrm{~cm}, \mathrm{SH} 69 \mathrm{~cm}, \mathrm{BL} 65 \mathrm{~cm}$, and EL $26 \mathrm{~cm}$. Based on breeding centers, the regions with ILEG goats were similar to the four national standards: BP, GDS, JW, KPB, LB, MAG, $M D, M W, N S U$, and TSB. Some regions such as $\mathrm{BL}, \mathrm{SP}$, and $\mathrm{SS}$ only fulfilled national standards for $\mathrm{CC}, \mathrm{SH}$, and BL measurements but not up to the EL measurement standards. EL size was smaller than that of the national standard of ILEG because the ILEG had a more genetic composition of Kacang goats than Etawah goats 
(ear length inherited from Etawah goats). The morphometric body at $\mathrm{CC}, \mathrm{BL}$, and $\mathrm{SH}$ was higher than goats in the central zone of Tigray, Ethiopia (Birhanie et al., 2019). The average body morphometry, especially HG, was also higher than that of other breed goats, such as Damascus goats $(72.67 \mathrm{~cm})$ and Kilis goats $(69.70 \mathrm{~cm})$ raised in the Southeastern Anatolia Region of Turkey (Tartar et al., 2019).

Table 2. The Average and Variance Components of Morphometric body ILEG Does

\begin{tabular}{|c|c|c|c|c|c|c|c|c|c|c|c|c|c|c|c|c|}
\hline \multirow[b]{3}{*}{ Traits } & \multirow[b]{3}{*}{ Terms } & \multicolumn{15}{|c|}{ Village Breeding Centers } \\
\hline & & BL & BP & GDS & JW & KPB & LB & MAG & MD & MW & NSU & SK & $\mathrm{SP}$ & SS & TSB & \\
\hline & & & & & & & & & & & & & & & & \\
\hline \multirow[t]{2}{*}{ data } & $\mathrm{N}$ & 53 & 23.02 & 40 & 50 & 24 & 55 & 30 & 60 & 39 & 24 & 19 & 37 & 24 & 19 & 513 \\
\hline & & & & 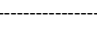 & 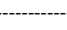 & ינינים & 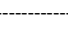 & --unit (cn & - & 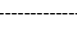 & - & 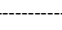 & 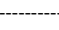 & -...-. & & Mean \\
\hline \multirow[t]{2}{*}{ CC } & Mean & 75.3 & 85.26 & 81.18 & 83.8 & 85.5 & 85.7 & 84.77 & 81.64 & 81.67 & 84.73 & 71.6 & 78.5 & 75.3 & 80.05 & 81.06 \\
\hline & VP & 5.53 & 2.91 & 6.36 & 4.93 & 5.79 & 2.64 & 3.38 & 4.42 & 4.66 & 6.67 & 4.53 & 3.14 & 4.96 & 5.13 & 4.63 \\
\hline \multirow[t]{2}{*}{ BL } & Mean & 72.4 & 82 & 78.02 & 79.5 & 78.2 & 81.36 & 82.67 & 80.73 & 77.59 & 76.87 & 68.1 & 72.5 & 71.7 & 73.42 & 76.64 \\
\hline & VP & 6.8 & 2.22 & 6.35 & 4.08 & 3.58 & 2.29 & 3.55 & 4.83 & 6.67 & 3.91 & 4.99 & 2.35 & 4.29 & 5.14 & 4.33 \\
\hline \multirow[t]{2}{*}{ SH } & Mean & 73 & 81.08 & 78.18 & 77.8 & 77.7 & 79.67 & 82.67 & 78.73 & 76.13 & 70.53 & 65 & 69.2 & 69.6 & 78.32 & 75.34 \\
\hline & VP & 5.04 & 2.11 & 4.68 & 7.43 & 4.59 & 2.19 & 3.03 & 4.51 & 11.15 & 18.23 & 5.12 & 1.94 & 4.92 & 4.14 & 5.83 \\
\hline \multirow[t]{2}{*}{ EL } & Mean & 25.7 & 30 & 29.7 & 33.7 & 28.8 & 28.07 & 29.17 & 28.71 & 27.67 & 27.4 & 21.4 & 23.7 & 24.4 & 27.68 & 27.44 \\
\hline & VP & 4.67 & 1.84 & 3.45 & 13 & 3.94 & 2.04 & 0.83 & 1.09 & 2.2 & 3.42 & 2.27 & 1.53 & 1.28 & 2.47 & 3.02 \\
\hline \multirow[t]{2}{*}{ EW } & Mean & 10.5 & 15.62 & 10.73 & 13.9 & 11.4 & 12.8 & 17.13 & 17.36 & 12.67 & 10.6 & 11.5 & 10.9 & 11.5 & 10.32 & 12.49 \\
\hline & VP & 4.58 & 1.55 & 1.63 & 4.85 & 2.08 & 1.8 & 1.36 & 1.11 & 1.47 & 1.06 & 0.85 & 0.9 & 0.83 & 1.16 & 1.73 \\
\hline \multirow[t]{2}{*}{ TL } & Mean & 21.9 & 26.41 & 27.8 & 29.1 & 28.5 & 23 & 26.26 & 24.71 & 23.08 & 27.8 & 21.7 & 22.2 & 23.3 & 27.74 & 25.16 \\
\hline & VP & 5.35 & 1.45 & 5.45 & 5.03 & 4.61 & 1.88 & 5.28 & 1.67 & 1.86 & 5.23 & 1.49 & 1.82 & 1.17 & 4.51 & 3.27 \\
\hline \multirow[t]{2}{*}{ LHT } & Mean & 18.2 & 27.82 & 20.43 & 31.7 & 27.8 & 26.91 & 23.97 & 14.81 & 20.82 & 25.13 & 20.5 & 19.5 & 21.9 & 23.05 & 23.02 \\
\hline & VP & 5.81 & 9.51 & 8.99 & 4.47 & 9.24 & 1.9 & 0.99 & 0.84 & 2.52 & 8.61 & 1.9 & 1.42 & 1.74 & 4.75 & 4.35 \\
\hline \multirow[t]{2}{*}{$\mathrm{PH}$} & Mean & 76 & 83.1 & 80.75 & 77.6 & 82.3 & 20.3 & 83.57 & 39.36 & 80.97 & 81.47 & 68.2 & 72 & 72.6 & 81.58 & 71.00 \\
\hline & VP & 4.68 & 2.17 & 4.53 & 14.4 & 3.48 & 0.89 & 3.01 & 2.22 & 5.12 & 4.7 & 5.03 & 2.37 & 5.27 & 3.67 & 4.31 \\
\hline \multirow[t]{2}{*}{ PW } & Mean & 18.6 & 20.26 & 22.28 & 24.9 & 19.7 & 82.73 & 20.67 & 9.94 & 19.79 & 19.53 & 18 & 18.6 & 18.1 & 16.63 & 24.26 \\
\hline & VP & 3.55 & 1.02 & 4.18 & 15 & 2.14 & 2.15 & 0.84 & 0.89 & 0.98 & 2.26 & 0.94 & 0.62 & 0.95 & 2.19 & 2.55 \\
\hline
\end{tabular}

One SK breeding village did not comply with the criteria of the three national standards (CC, $\mathrm{SH}$, and EL size were lower than national standards). The ILEG in the region had genetic composition dominated by Kacang goats rather than Etawah goats. It noted that the does standard of Kacang goats from the Ministry of Agriculture Republic of Indonesia (2015) was CC $66.7 \pm 5.2 \mathrm{~cm}, \mathrm{BL} 58.9 \pm 5.6 \mathrm{~cm}, \mathrm{SH} 55.6 \pm 4.2$ $\mathrm{cm}$, and EL with a medium category. In contrast, the ILEG in SK village breeding was higher than the Kacang goat with $\mathrm{CC}$ of $71.6 \pm 4.53 \mathrm{~cm}, \mathrm{BL}$ $68.1 \pm 4.99 \mathrm{~cm}, \mathrm{SH} 65 \pm 5.12 \mathrm{~cm}$, and $\mathrm{EL} 21.4 \pm$ $2.27 \mathrm{~cm}$.
The variance of the morphometric body in this research (3.93) was lower than 28.17 reported by Belkhadem et al. (2019) who investigated the variation of local does of 5 areas in Western Algerian countries. It showed that the morphometric body of ILEG was more uniform compared to that of local goats in western Algerian countries.

Based on one way, ANOVA showed a highly significant difference $(P<0.01)$ in various areas of goat breeding based on morphometry body. The size of $\mathrm{CC}, \mathrm{EL}, \mathrm{EW}, \mathrm{TL}$, and $\mathrm{PH}$ in various regions $>50 \%$ were not significantly different ( $P>0.05)$. In contrast, in BL, SH and LHT, only < 
$36 \%$ village breeding center was not significantly different $(P>0.05)$. It indicated that $\mathrm{BL}, \mathrm{SH}$, and $\mathrm{LHT}$ were more varied than $\mathrm{CC}, \mathrm{EL}$, $\mathrm{EW}, \mathrm{TL}$, and $\mathrm{PH}$. Therefore, selection based on $\mathrm{BL}, \mathrm{SH}$, or LHT was more effective than $\mathrm{CC}, \mathrm{El}$,
$\mathrm{EW}, \mathrm{TL}$, or $\mathrm{PH}$. The coefficient of variance the prolific trait and morphometric bodies was calculated from standard deviation divided by the means are presented in Table 3

Table 3. The Coefficient of variance in the prolific trait and morphometric body of does ILEG

\begin{tabular}{llcc}
\hline No & Area Code & $\begin{array}{c}\text { Coefficient of Variation for } \\
\text { prolific trait (\%) }\end{array}$ & $\begin{array}{c}\text { Coefficient of Variation for } \\
\text { morphometric body (\%) }\end{array}$ \\
\hline 1 & BL & 51.27 & 5.20 \\
2 & BP & 38.76 & 3.31 \\
3 & GDS & 47.78 & 4.72 \\
4 & JW & 37.26 & 5.68 \\
5 & KDR & 26.80 & 4.28 \\
6 & LB & 42.52 & 2.87 \\
7 & MAG & 39.18 & 3.14 \\
8 & MD & 48.49 & 3.71 \\
9 & MW & 37.65 & 4.32 \\
10 & NSU & 46.24 & 5.20 \\
11 & SK & 45.20 & 4.27 \\
12 & SP & 43.33 & 3.11 \\
13 & SS & 47.46 & 3.89 \\
14 & TSB & 42.08 & 4.12 \\
& Average & 42.43 & 4.13 \\
\hline
\end{tabular}

The expression of the prolific trait was more diverse than the morphometric body (Table 3.) because the breeders did not make the selection with considering prolificacy potential but solely on external performance, especially in buck selections with a natural mating system. The variation of a trait in a livestock population, including genetic variation, was significant as an asset for selection to increase the livestock's genetic trend in the future for economic sustainability (Hassan et al, 2016 and Atoui et al., 2018).

\section{Estimation of Breeding Values (EBVs) of prolific potency}

Heritability estimates of prolific traits were $0.20(n=20)$ with variance component of dam 0.18 , covariance component of dam and daughter 0.02 . Repeatability estimates of the prolific characteristic were 0.89 with variance component of dam 2.18 and variance component between progeny within female 0.27 .
The EBVs average prolific potency of the ILEG Does in 14 regions (478 data) in East Java was $1.55 \pm 0.16 \mathrm{~kg}$ with a minimum of the prolificacy of 1.39 and a maximum prolific potency of 2.23 (Table 4).

The EBVs data (Table 4) showed that the average EBVs from lowest to highest were 1.481.74 , with a standard deviation of $5-24 \%$ of 478 does in various breeding villages. EBVs of MAG, BP, MW, and LB $(28 \%$ of 4 regions of 14 breeding villages) were higher than the average population EBVs (1.55 heads/calving). It indicated that the mean of EBVs for prolific traits was in the medium range with a reference that the prolificacy of sheep had $>2.23$ heads/doe was the high category, >1.20-1.82 heads/doe was the medium category, and $<1.20$ heads/doe was a low category. The breeding value research gave guidelines to improve indigenous goats' genetic quality (Al-Samarai et al., 2019). The EBV relation with the prolificacy trait was essential to improve population reproduction parameters (Abdouli et al., 2019). 
Mudawamah et al. /Animal Production. 23(1): 54-61, 2021

Accredited by Kemenristek Dikti No 32a/E/KPT/2017. ISSN 1411-2027

Table 4. The EBVs average prolific potency of The ILEG Does

\begin{tabular}{clrrrrr}
\hline No & Region & Means & S & N & \multicolumn{2}{c}{ max } \\
\hline 1 & MAG & 1.74 & 0.16 & 47.00 & 2.23 & 1.39 \\
2 & BL & 1.52 & 0.09 & 48.00 & 1.98 & 1.50 \\
3 & BP & 1.56 & 0.16 & 47.00 & 2.11 & 1.39 \\
4 & MD & 1.54 & 0.13 & 35.00 & 1.98 & 1.39 \\
5 & GDS & 1.52 & 0.08 & 40.00 & 1.74 & 1.39 \\
6 & JW & 1.49 & 0.11 & 53.00 & 2.11 & 1.39 \\
7 & SK & 1.49 & 0.17 & 10.00 & 1.86 & 1.39 \\
8 & KPB & 1.48 & 0.05 & 27.00 & 1.50 & 1.39 \\
9 & MW & 1.68 & 0.20 & 43.00 & 1.98 & 1.39 \\
10 & LB & 1.56 & 0.14 & 54.00 & 1.98 & 1.39 \\
11 & NSU & 1.50 & 0.21 & 20.00 & 2.11 & 1.39 \\
12 & SP & 1.54 & 0.11 & 16.00 & 1.86 & 1.39 \\
13 & SS & 1.51 & 0.17 & 25.00 & 1.98 & 1.39 \\
14 & TSB & 1.48 & 0.24 & 13.00 & 2.11 & 1.39 \\
\hline
\end{tabular}

EBVs distribution of does prolific trait from 14 regions (MAG till TSB) in East Java (Figure 1)

Figure 1 shows that the EBV profile of breeding village centers based on boxplot analysis was divided into four shapes. The first EBV profile was the MAG, MW, and TSB regions with a Q1 value between 1.39-1.5, a Q2-Q3 value greater than 0.1 , and a Q3-Q2 value greater than 0.1 . The second EBV profile was the region $\mathrm{BP}, \mathrm{LB}, \mathrm{MD}, \mathrm{NSU}, \mathrm{SK}$, and SS with a Q1 value between 1.39-1.5, a Q2-Q3 value greater than 0 , and a $\mathrm{Q} 3-\mathrm{Q} 2$ value greater than 0.1 . The third EBV profile was the region of $\mathrm{BL}, \mathrm{GDS}, \mathrm{KPB}$, and $\mathrm{SP}, \mathrm{Q} 1$ values between 1.39-1.5, Q2-Q3 values greater than 0 , and Q3-Q2 values greater than 0 .

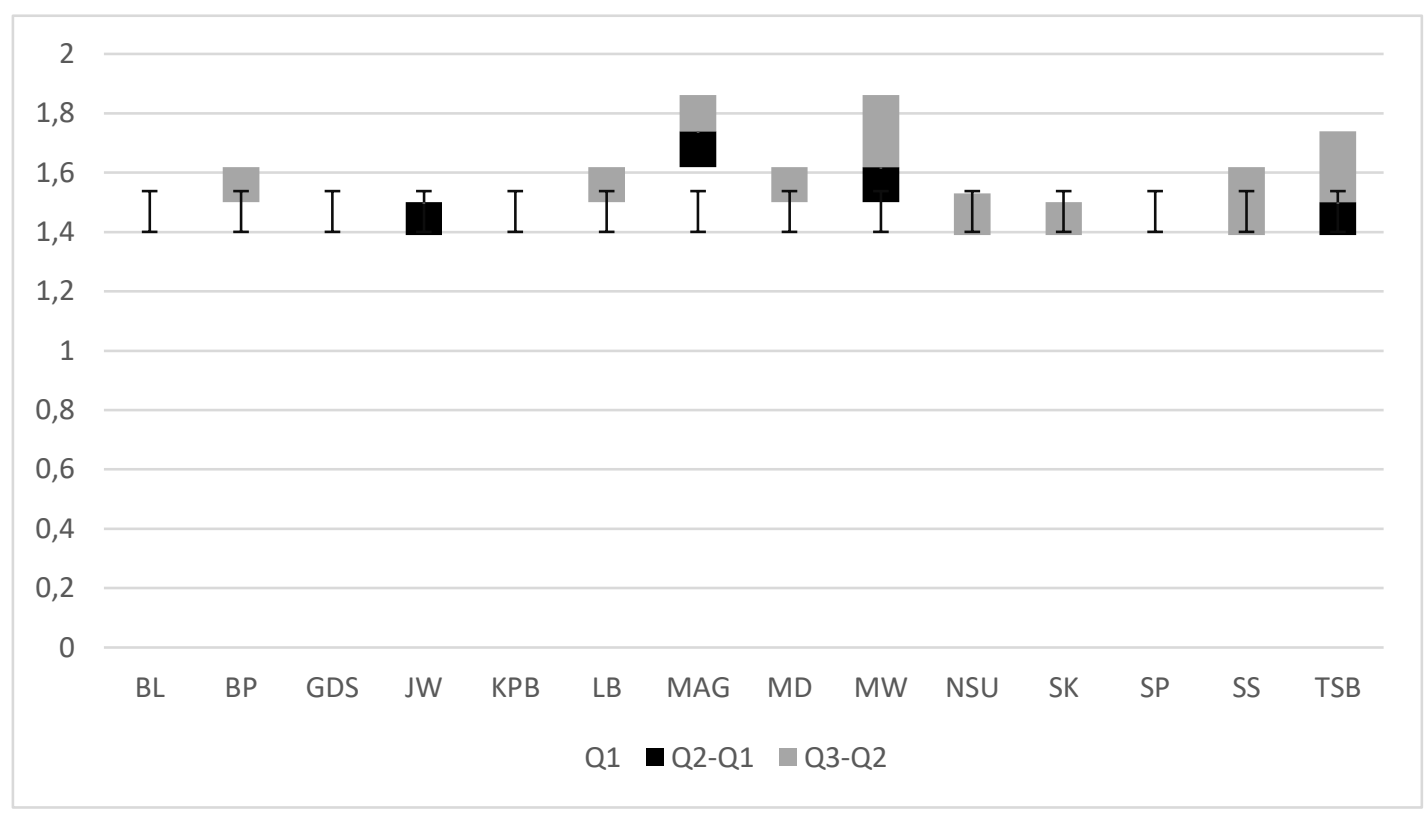

Figure 1. Profile of Does EBVs for prolific traits with Quartile (Q) in 14 regions of ILEG in East Java

EBVs for the prolific traits reflected the prolific prediction of offspring in the optimal potency if kept in the same environment as the ancestor. It confirms previous studies that a selection of doe and buck candidates must use EBV values for subsequent breeding programs 
to accelerate genetic progress in the village breeding center (Chawala et al., 2017; Gizaw et al., 2011) and to establish sustainable breeding for national scale (Aljumaah, 2019).

\section{Conclusions}

ILEG prolificacy in the present study ranged from medium to high category. The variation of a prolific trait was higher (43.98\%) compared to that of the morphometry body. The prolificacy EBVs was divided into four unique pattern boxplots. The prolific variance of ILEG had great potential for a breeding program through selection or mating program.

\section{Acknowledgement}

The authors thank the Higher Education, Directorate of Research and Community Service, Ministry of Research, Technology and Higher Education, Republic of Indonesia for the research grant of Applied Research.

\section{References}

Abdoli, R, P Zamani, SZ Mirhoseini, NG HosseinZadeh and M Almasi. 2019. Genetic parameters and trends for litter size in Markhoz goats. Rev Colomb Cienc Pecu 32(1): 58-63.

Abraham, H, S Gizaw and M Urge. 2018. Identification of breeding objectives for Begait goat in western Tigray, North Ethiopia. Tropical Animal Health and Production. 50 (8): 1887-1892.

Aljumaah, RS. 2019. Stimulated genetic gain of a close breeding program for Ardi goat in Saudi Arabia. Journal of The Saudi Society of Agricultural Sicences. 18(4): 418-422.

Al-Samarai, WI, RHA Senkai and HM Al-Khuzai. 2019. Estimation of breeding values and genetic variance depending on lactoferrin gene polymorphism in Iraqi goat breed. Plant Archives. 19(1): 1257-1260.

Atoui, A, MJ Carabano and S Najari. 2018. Evaluation of a local goat population for fertility traits aiming at the improvement of its economic sustainability through genetic selection. Spanish Journal of Agricultural Research. 16(2): 1-7.
Bett, RC, AM Okeyo, IS Kosgey, AK Kahl and KJ Peters. 2012. Evaluation of alternatives selection objectives and schemes for optimization of village goat improvement programs. Livestock Research for Rural Development. 24(1).

Birhanie, $M, K$ Alemayehu and $G$ Mekuriaw. 2019. Morphological characterization of goat population in central zone of Tigray, Ethiopia. Tropical Animal Science Journal. 42(2): 81-89.

Belkhadem, S, H Tefiel, I Belantar, M Chahbar and SBS Gaouar. 2019. Discriminant analysis on the morphometry of local goats breed in the western of Algeria. Genetics and Biodiversity Journal. 3(2): 49-56.

Chawala, AR, G Banos, DM Komwihangilo, A Peters and MGG Chagunda. 2017. Phenotypic and Genetic parameters for selected production and reproduction traits of Mpwapwa cattle in low inpu production systems. South African Journal of Animal Science. 47(3): 307-318.

Gizaw, S, T Getachew, M Tibbo, A Haile and T Dessie. 2011. Congruence beween selection on breeding values and farmer's selection criteria in sheep breeding under conventional nucleus breeding schemes. Animal. 5(7): 995-1001.

Goddard, ME and BJ Hayes. 2009. Mapping genes for complex traits in domestic animals and their use in breeding programmes, Nat. Rev. Genet. 10(1): 381-391.

Haldar, A, P Pal, M Datta, R Paul, SK Pal, D Majumdar, CK Biswas and S Pan. 2014. Prolificacy and Its Relationship with Age, Body Weight, Parity, Previous Litter Size and Body Linear Type Traits in Meat-type Goats. Asean-Australas J. Animal Sci. 27(5): 628-634.

Hassan, MR, A Iqbal, S Sultana and MAI Talukder. 2016. Estimation of heritability, breeding values and genetic trends for growth traits of exotic goat. International Journal of Natural Sciences. 3(1-4): 7-11.

He, Y, X Ma, X Liu, C Zhang and J Li. 2001. Candidate Genes Polymorphism and Its Association to Prolificacy in Chinese Goat. Jounal of Agriculture Science. 2(1): 88-92.

Kasap A, B Mioc, D Skorput, V Pavic and Z Antunovic. 2013. Estimation of Genetic 
Parameters and Genetic Trends for Reproductive Traits in Saanen Goats. Acta Veterinaria (Beograd). 63(2-3): 269-277.

Ling, YH, Q Quan, H Xiang, L Zhu, MX Chu, XR Zhang and CY Han. 2015. Expression pro les of differentially expressed genes affecting fecundity in goat ovarian tissues. Genetics and Molecular Research. 14(4): 1874318752.

Mdladla, K, EF Dzomba and FC Muchadeyi. 2017. Characterization of the village goat production system in the rural communities of the Eastern Cape, Kwazulu-Natal, Limpopo and Nort West Provinces of South Africa. Tropical Animal Health and Production. 49: 515-527.

Margatho, G, V Rodriguez-Estevez, H Quintas and J Simoes. 2019. The effects of reproductive disorder, parity, and litter size on milk yield of Serrana goats. Animals. 9(968): 1-11.

Ministry of Agriculture Republic of Indonesia, Directorate of Animal Breeding and Production of Animal Husbandry and Animal Health. 2015. Determination of Kacang goat family. Bibit.ditjen_pkh.pertanian. go.id/ sites/ files/ default/ kambing20\%kacang.pdf.

Ministry of Agriculture Republic of Indonesia, Directorate General of Animal Husbandry and Animal Health. 2018. Livestock and Animal Health Statistic. http://ditjen pkh. Pertanian.go.id/ userfiles/ File/ Buku Statistik 2018-Final_ ebook.pdf? time = 1543210844103.

Mudawamah, M, ID Retnaningtyas, MF Wadjdi, Badriyah, S Susilowati, Aulanni'am and G Ciptadi. 2014. Analysis of Genetic Similarity between PE Goats Derived from Natural
Service and Artificial Insemination by RAPDDNA. Jurnal Kedokteran Hewan. 8 (2): 138141.

Mudawamah, M, MZ Fadli, G Ciptadi, U Ali and GR Putri. 2019. Reapeted G-nucleotides from DNA sequences from RAPD results in Indonesian Local Etawah Goats derived from natural service and artificial insemination. Jurnal AIP Conference Proceedings, 050013: 1-4. https://doi.org/ 10.1063/1.5061906.

National Standard Agency. 2015. Indonesian National Standard (SNI) of goat germs-Part 1: Etawah crossbreed SNI 7352.1: 2015.

Pascal, C and N Zaharia. 2016. Evaluation of the reproduction function of goats in Romania. Seria Zootechni. 65: 9-13.

Pai, A and AK Chakravarty. 2020. Disease resistance for different livestock species. 2020: 271-286.

Samardzija, M, S Vince and D Duricic. 2013. Association of parity, fecundity and body condition score with blood serum concentration of some metabolites during pre and post parturient period in German Improved Fawn goats. Veterin. Arski arkhiv 83(5): 469-477.

Schwartz, HJ. 2017. Eco-system of agricultural landscape and sustainable land use: livestock system. Faculty life science. Albrect-BadielThaer Institut for Agricultural and Holticultural Sciences. amor.cms.huberlin.de/ h1981d0z/lehre/eco/INRMpdf/02-3.pdf. pp. 1-19.

Tartar, AM, SS Tuncer and HD Sireli. 2019. Comparison of yield characteristics of Damascus and Kilis goats in dry climate condition. Aus. J. of Vet. Sci. 51(1): 61-66. 